\title{
"My Turn to Speak": Criticism Culture and the Multiple Uses of Class in Postwar North Korea
}

\author{
Andre Schmid*
}

\section{Introduction}

The question "What happened to the concept of class in North Korea after the war?" is hardly a straightforward one. As in other postrevolutionary socialist countries, class remained central to the ruling ideology of the Korean Workers' Party (KWP). Congresses reiterated its significance, leaders acclaimed its transformational potential, and the media were filled with exhortations for the entire population to elevate their class consciousness. Calls for greater attention to class politics inevitably became intertwined with the new political practice of personal and small group criticism. ${ }^{1}$

This paper examines the complex and vexed relationship between class, ideology, and the rise of what I call criticism culture. While the Partystate presented class and class consciousness as an unitary category, this paper argues that in fact no single definition of class prevailed, as multiple ways of using this key socialist category evolved in different political

\footnotetext{
* Associate Professor, Department of East Asian Studies, University of Toronto

1 My thanks to three anonymous reviewers for their recommendations, especially for introducing me to the work of Kim Chaeung. An earlier version of this paper was presented at a North Korean social history workshop at the School of Oriental and African Studies, 2015.
} 
and social contexts. Rather than turn to dictionaries for a single meaning of class or examine Kim Il Sung speeches for an authoritative definition, this paper examines a number of public sources that were read and written by postwar North Koreans as part of the emergence of criticism culture to consider the flexibility of the usages of class language. By exploring some of the challenges faced by the KWP in making criticism part of a nation-wide political practice together with the ways workers framed their criticisms, this paper investigates conceptions of class as they took form not in high level theoretical journals or in public political trials but in the local social worlds of workers. That this difference even existed shows how ideology was not monolithic.

As the practice of criticism spread from a form of political critique within the ranks of the Party to a wider movement involving the entire population, the KWP encountered a number of dilemmas. Most importantly, criticism became the source of much anxiety. This was true not just for the population who were experiencing a dramatically novel form of political engagement, but also for one of the KWP affiliated mass organizations, the General Federation of Trade Unions, which was charged with the ideological well-being of workers. Although in theory criticism served to solidify proletarian consciousness, I argue the Federation quickly became anxious that this fundamental ideological project threatened to alienate the very workers at whom it was aimed. Tracing a number of personal accounts published in the media by individuals involved in the early institutionalization of criticism, this paper begins by tracing measures undertaken to ensure criticism did not emerge to become a destabilizing force - an effort that reveals the still sensitive nature among the population of the reforms pushed by the KWP.

The second part of the paper examines one particular set of published workers' criticisms in the Federation's newspaper, the Nodongja sinmun (The Workers' Newspaper). In a regular column at the end of the 1950s entitled "My Turn to Speak" (Nado hanmadi), workers offered criticisms of their colleagues. An analysis of the language in these criticisms shows a specific understanding of class that vacated traditional Marxist class 
categories in favor of culturalist categories, which emphasized the selfreforming possibilities of the individual. My paper suggests this conceptual emphasis tempered local, everyday politics in the DPRK and made the type of radical use of class politics, as perhaps most commonly seen in its neighbor, the People's Republic of China, less tenable. In the particular historical setting of the postwar - precisely the time when newly promoted Party members were establishing themselves as the governing elite of a growing state recovering from war - the emergence of criticism culture, in fact, depoliticized class categories for the contemporary moment. By examining these sets of worker writings, this paper offers some preliminary thoughts on the complex relationship between criticism culture and class ideology that was so central to the revolutionary claims of this young Party-state. ${ }^{2}$

\section{Postwar Criticism Culture}

Criticism, whether self or small group, centered on ideology (sasang). And ideology - however collectively defined and however seen as fundamental to the revolution - ultimately came down to the individual. For all the writing about proletarian consciousness in theoretical journals such as Kulloja, in the KWP's central newspapers such as Rodong sinmun or (eventually) in Kim Il Sung's speeches, the challenge facing local levels of the KWP and mass organizations as well as each member of the population was how to cultivate proper individual consciousness or thought. The practice of criticism began in the pre-war period, even if some Soviet advisors felt Koreans were too restrained in its implementation. ${ }^{3}$ In the

2 I would add that this is not a paper analyzing new class formations in North Korea but the way class has been invoked in various North Korean settings.

3 Kim Chaeung, "PukHan ŭi inmin kukka kŏnsŏl kwa kyekŭp kujo chaep'yŏn, 1945-1950" (The Construction of the People's State and Re-organization of Class Structure in North Korea, 1945-1950). Seoul: Koryo University dissertation, 2014: 
postwar period, criticism took on an especially urgent note given the fact that not insignificant numbers of Party members headed south during the war. ${ }^{4}$ Additionally, most of the Party cadres did not have, in the KWP's own terminology, sufficient levels of knowledge - or as Pak Kumch'ŏl put it in one 1957 assessment, most Party members did not even have five years of experiencing "Party life" (tang saenghwal). ${ }^{5}$ These specific factors elicited a call to "heighten ideological training," but that was not all.

More sweepingly, the KWP officially in its 1955 congress, and less overtly upon the conclusion of the war in its many sponsored publications, emphasized the laggardness of the general population on the ideological front. ${ }^{6}$ This assessment had two distinct stages, both resting on an assessment of the material conditions of the revolution. Between 1953-58, when the economy had been largely but not entirely collectivized, this assessment of the unpreparedness of the population combined with a worry that those remaining bourgeois and petty bourgeois elements, however much under the control of the Party, nevertheless posed an ideological threat as they mingled with a population not yet steeled to resist temptations. In a still tensely divided peninsula, the few remaining landowners and merchants were deemed the natural partners for the machinations of

\section{8-350.}

4 Yi Chuch'ŏl, Chosŏn Nodongdang dangwŏn chojik yŏn'gu, 1945-1960 (Research on the Membership and Organization of the Korean Workers' Party). Seoul: Sŏnin, 2008:100-141; also see Sŏ Tongman, PukChosŏn sahoejuŭi ch'eje sŏngnipsa, 1945-1961 (The Establishment of the North Korean Socialist System, 1945-1961). Seoul: Sŏnin, 2005.

5 Pak Kumch'ŏl, Tang ŭi t'ongil kwa tangyŏrrŭl tŏuk kanghwahald e taehayŏ (For the Further Strengthening of Party Unity and Solidarity). Pyongyang: Chosŏn nodongdang ch'ulp'ansa (The Labor Party Press), 1958: 7.

6 See Kim Ilsung's speech to Party members at the conclusion of the Party congress of April 1, 1955, "Sahoejuŭi hyŏngmyŏng ŭi hyŏndangye e issŏsŏ tang mit kukka saŏp ŭi myŏtkaji munje tŭl e taehayŏ" (Concerning Several Problems with Party and State Enterprise in the Current Stage of the Socialist Revolution), Kim Il Sŏng Chójakjip. Pyongyang: Nodongdang ch'ulp'ansa (The Labor Party Press), 1979: volume 18, 57-87. 
the Americans and their South Korean allies - eager, if we are to believe these sources, to promote what was called "American-style living" (Miguksik saenghwal). ${ }^{7}$ By 1958, with the last push towards the collectivization of agriculture and the incorporation of the little commercial trade into the public distribution system, the means of production came to be completely socialized. ${ }^{8}$ The transition to socialism was made official.

Yet ironically, this transition resulted in an even greater emphasis being placed on the ideological integrity of individuals. Since the economy had been socialized, it became difficult for the analysts of the many remaining socio-economic problems to rest their critiques on structural factors since, after all, there was little theoretical ground for material conditions, now socialized, to be the source of problems. The burden of resolving this tension was taken up by ideology. It now became the primary explanatory variable for most, if not quite all, social and economic problems. It was within the thinking of an individual, in short, that one could identify the source of socio-economic and other ills. The ideological burden, in turn, came to rest on individuals who through their own efforts - or more precisely, lack of sufficient effort - still fell short of the mark in what supposedly were superior material conditions. And, this burden, too, came to rest, in turn, on those lower level units charged with assuring the ideological rectitude of a population deemed redeemable but lacking. Ideology, in short, "lagged" behind material conditions - and something needed to be done about it. The answer became individual ideological work.

This was not just a postwar problem, of course. The issue of proletarian

7 For an extended discussion of American style living' see Miguksik saenghwal yangsik kwa namChosŏn e mich'in kŭ hugwa (American Life Style and Its Consequences for south Korea). Pyongyang: Chosŏn Rodongdang Ch'ulp'ansa, 1965. It also emerges as a major subject in the journal NamChosŏn munje (Problems of South Korean).

8 Kim Seungbo, NambukHan kyŏngje kujo ŭi kiwŏn kwa chŏn'gae (The Origins and Development of North and South Korean Economic Structures). Seoul: Yŏksa Pip'yŏngsa, 2000. 
consciousness began to be discussed in the liberation period. ${ }^{9}$ It is also not surprising to find that one of the journals published during the war was Sŏndongwŏn such'ŏp, the journal for propaganda workers, which regularly raised ideology and class issues as the war raged. ${ }^{10}$ As significant as this earlier work had been, it is not possible to exaggerate the emphasis on ideology for the postwar recovery of a Party and state that had barely survived an existential crisis. While its common to dismiss DPRK propaganda, it would be an error to misread the assertion made simultaneously at the highest levels and in the most mundane settings about how the fundamental task facing the Party was ideological. The KWP's assessment of the state of the revolution and re-emphasis on ideology was to shape everyone's life in the postwar era.

The priority given to ideology led to virtually endless initiatives and engagements on the ideological front. These moved far beyond the formal political sessions and the study of Marxist and Leninist thought or Party history in an era when it was still not de rigeur to quote Kim Il Sung. ${ }^{11}$ Indeed, formal study was arguably less important than the many other realms in which ideological work took place. A proliferation of advice literature on how to properly conduct oneself arose. ${ }^{12}$ Workers in dormi-

9 Suzy Kim, Everyday Life in the North Korean Revolution, 1945-1950. Ithaca: Cornell University Press, 2013 and Charles Armstrong The North Korean Revolution, 1945-50. Cornell University Press, 2003.

10 Anonymous, "Nalgŭn sasang kwa tu'jaenghaja" (Let's Struggle Against Outmoded Thought) Sŏngdongwŏn such'ŏp May 1952: 30-39. Production values for wartime magazines was low, as evidenced in this issue's alternatingly reversed pagination and low quality of printing/paper.

11 On the early shifts in Party history and the resurrection of the anti-Japanese guerilla group, see Kim Kwangun, Pukhan chŏngch'isa yŏn'gu I (North Korean Political History Studies I). Seoul: Sŏnin, 2003: 505-550 and Yi Chuch'ŏl, Chosŏn Nodongdang dangwön chojik yŏn'gu, 1945-1960. (Research on the Membership and Organization of the Korean Workers' Party). Seoul: Sŏnin, 2008: 513-555.

12 This culminated in a stand alone volume by Hwang Yŏngsik, Saenghwal ŭi kŏul (A View on Life). Pyongyang: Chosŏn Sahoejuŭi Rodong Ch'ŏngnyŏn Tongmaeng Ch'ulp'ansa (The Press of Chosŏn Socialism Labor Alliance), 1965. 
tories found their personal behavior scrutinized for the proper morality. These endeavours extended to issues of personal hygiene and public sanitation, to the creation of motherhood schools ( culture of cartoons, discussions of what constituted a worthy socialist photograph, the formulation of "production culture" (saengsan munhwa), ideals of how to go about appreciating movies and literature - to name just a few of the vast number of realms. These injunctions and exhortations were all about how to go about living, a seemingly mundane question linked to the very precarity of the success or failure of the revolution in a hostile, divided peninsula through one's individual ideological level. The challenge for the KWP was to harmonize lives to the socialist project - and ideology served that purpose.

Criticism had a special place among these activities. The long tradition of criticism in the history of socialism is well known and the KWP proclaimed its own tradition as part of its emerging history of its pre-1945 struggles. ${ }^{13}$ In the 1945 period, as Kim Chaeung has described, criticism became a much debated feature of Party life for KWP members. ${ }^{14}$ After the war, the usage of criticism came to be widely extended to the general population as part of the process of the postwar consolidation of centralized state power and presented as the continuance of pre-1945 Party tradi-

13 For just one Kim Il Sung speech where he reads criticism as central to the antiJapanese guerilla movement, see his January 15, 1961 speech, "Kyŏngje saŏp-e taehan tangjŏk chidowa t'ongjerŭl kanghwahald-e taehayŏ" (On the Strengthening of Party Leadership and Control of Economic Enterprises), Kim Il Sŏng Chŏjakjip Pyongyang: Nodongdang Ch'ulp'ansa (The Labor Party Press), 1979: volume 25: 64-89; comparatively see Martin King Whyte, Small Groups and Political Ritual in China. Berkeley: University of California Press, 1974; in the long history of criticism as denunciation in Europe see Sheila Fitzpatrick and Robert Gellately, eds., AccusatoryPractices: Denunciation in Modern Europe, 1789-1989. Chicago: Chicago University Press, 1997.

14 Kim Chaeung "PukHan ŭi inmin kukka kŏnsŏl kwa kyekŭp kujo chaep'yŏn, 19451950" (The construction of the people's state and re-organization of class structure in North Korea, 1945-1950). Seoul: Koryo University dissertation, 2014: 345350. 
tions. Criticism came to be routinized in mass organizations and in political study sessions. It also came to be regularized in review meetings at work places and neighborhoods. Quickly, a criticism culture emerged. Political discourse could not be separated from criticism as fundamental to ideological cultivation (sasang kyoyang) and was expected of everyone.

\section{Criticism as Anxiety}

It is also clear that criticism culture emerged rife with anxieties. While these anxieties were manifold, this paper restricts itself to three: i) anxieties on the part of Party-state authorities about how this new political practice would be received by the population, ii) anxieties on the part of segments of the population on criticism's implications for their own lives and what was required in making one's own interiority the subject of explicit public concern, and iii) anxieties about how local agents should go about using criticism to salutary purposes. Thus, as part of this criticism culture, there emerged -without any irony - a criticism of the praxis of criticism, which rested on this range of anxieties and took the form of a discussion of best practices. This emerged in part as a result of the controversies arising in the pre-war period. Criticism had elicited much conflict among Party members, as individual members used this forum for personal revenge or lost their tempers when they received criticism. ${ }^{15}$ Postwar efforts sought to overcome these shortcomings.

The centrality of criticism to postwar reconstruction was captured in a typical article published in the same month as the armistice. ${ }^{16}$ Writing for youth, Ri Hongjong expounded the logic that criticism constituted a fundamental element in the struggle to build socialism. Criticism, he touted,

\section{Ibid 349.}

16 Ri Hongjong, "Pip'an kwa chagi pip'an ŭn tongmaeng saŏp paljon ŭi kangryŏkhan sudan" (Criticism and Self-criticism Are a Powerful Means for Advancing the Task of Solidarity). Ch'óngnyŏn saenghwal 5 (July 1953) 22-32. 
served as a vehicle for change. Intended as a reference material for others to adopt in their own small group setting, Ri's article equated mutual and self-criticism with weapons. He recounted the long history of criticism, finding its original spirit in the critical nature of Marxist-Leninism itself, which 'from its first day' had only developed due to its fearless criticism of others and self. This spirit needed to be continued today, he argued, taken up by the entire population. "Criticism and self-criticism are a decisive means of defeating all the outmoded and dying forces that harm our progressing movement. They are powerful and sharp weapons for uprooting all corruption and conservatism, stagnation and passivity. They purge the vestiges of colonial and feudal thought, as well as the remains of Japanese bourgeois thought." These were ringing words in which Ri rooted his conception of postwar reconstruction along the lines of class warfare.

In explaining this commitment, Ri determinedly proclaimed the Party "is not afraid of criticism and self-criticism." This was a form of rhetoric typical of the self-confident, upper-level political writing. Like so many essays published in these early postwar years, it captured in form and tone a sense of the inevitable unfolding of history in the direction projected by the Party. Yet as much as Ri trumpeted the undaunted resolve of the Party in this early piece, over subsequent years as criticism came to be instituted as a widespread political practice, this type of bravado became insinuated with a second, more anxious form of discussing the very same challenges.

As with many of the regime's new policies, this may not have been so much an issue with the usual assortment of "enthusiasts" (yŏlsŏngja), "centers" (haeksim), propaganda workers (sŏndongwŏn), and retired soldiers who often took the lead in organizing criticism in settings throughout the country. Yet Ri's bold denial of fear, in fact, glossed over what was to become a clear dilemma implicitly recognized by the Party: many people were afraid of the consequences of this radical form of political and social practice. Not everyone was as keen as Ri assumed and his style of heated rhetoric likely engendered much unease. When the All Party Congress in 1955 reiterated the importance of criticism, the press simul- 
taneously featured a flurry of articles with a very different tone. In place of calls for class warfare and a call to arms, these articles sought to assuage popular misgivings about criticism, which had arisen in the two years since Ri's piece.

Among this coverage, two types of articles are relevant here. The first concerned the workers in their everyday lives, representing them in classic worker-enlightenment stories as unsettled by the introduction of this new form of political practice. These articles sought to demonstrate often with rhetoric toned down and in first person narratives - the benefits of criticism less in terms of the grandiosity of revolutionary goals and more in terms of the benefits to be reaped in day-to-day life. Here criticism was less about hastening the inevitable construction of communism in the future but more about not making mistakes in the work place or being tidy at home. These were not the daunting dilemmas of material dialectics but the mundane challenges of quotidian life. Such a focus demonstrated not only the political direction of criticism but also that the Party had become fully aware that many people needed convincing.

The second type of article targeted low level propaganda workers, who - however well-intended - became overzealous in their criticism of others. This is not surprising. In the early postwar years, as a dizzying array of new central policies came to be implemented, high level leaders often sought to rein in local leaders who, out of ignorance, over-zealousness or heavy-handedness, acted counter to the goals and spirit of the central Party. This occurred in areas as diverse as implementing the new wage system, erringly interpreted by some as equal wages for all. This was not socialism, they had to be repeatedly told. Others had to be warned by none other than Kim Il Sung and other leading sources not to be too swift in implementing songbun social categories given the complexities of the population's social and political backgrounds. ${ }^{17}$ Likewise, in its early

17 For one example, see Kim Il Sung's December 4, 1959 speech "Sahoejuŭi kyŏngje kŏnsŏl esŏ nasŏnŭn tangmyŏnghan myŏt kaji kwaŏp tŭl e taehayŏ” (Concerning Some Tasks Arising in the Construction of a Socialist Economy) Kim Il Song 
years of implementation, criticism came to be waywardly carried out. This was never quite openly stated. Yet in the large number of articles published in these two categories, the repetition of represented themes in the lives of these workers reflects a common purpose: to smoothen the rough path the implementation of criticism had taken - without, of course, ever questioning criticism as a strategy of governance. They were about best practices that would enable a 'productive' criticism without generating a backlash.

This was the context for the publication of one personal account of how a worker overcame his fear and resentment to make his peace with criticism. ${ }^{18}$ Written by Kim Ǔngsŏn, a sheet metal worker at the Pukchŭng Machine Manufacturing Plant, this first person account was typical of model worker stories, in this case narrating the unfolding of the author's personal self-awareness, a rise to self-consciousness through the process of criticism. In fact, the story was itself a form of self-critique, the ultimate performance of the transformed self, able to confess its shortcomings in a very public forum. Kim began by admitting that like many others he originally did not fully appreciate the function of criticism. This became clear when a co-worker got upset at him for doing a shoddy job cutting sheet metal for the oil tanks they were producing, "Comrade Ŭngsŏn," he was warned after mis-sizing his cuts, "you have to be more responsible for your errors." But Kim's response was anything but ideal:

Chójakjip (Pyongyang: Nodongdang ch'ulp'ansa (The Labor Party Press)), 1979: volume 24, 393-46, especially sections 454-56. For an article criticizing officials for being too quick in labeling some as 'bad people' rather than going through slow work of ideological training, see "Chohapwŏn tŭl ŭi kyegŭp chŏk kaksŏng ŭl nop'i wihayǒ" (Towards Raising the Class Awareness of Collective members), Rodong sinmun May 8, 1959. And for a warning to cadres not to overemphasize songbun, see 'Ch'ogŭp tang tanch'e tŭl esŏ pidangwŏn tŭl wa ŭi saŏb ŭl ŏttŏke halgŏsinga?" (How to Deal with non-Party Members in Low Level Party Units). Tangganbudŭl ege chunün ch'amgo charyo October 1960: 20-25.

18 Kim Ŭngsŏn, "Pip'ankwa chagi pip'an" (Criticism and self-criticism) Rodongja (The Labor) June 1955: 19-22. 
he stewed over the criticism, believing the fault lay with others - a point he made clear to his critic. Later that day, at an evening work review meeting, Kim heard the same point repeated by several other colleagues. "They were right," he finally and begrudgingly admitted, but Kim described himself as nevertheless remaining resentful in a corner of his heart. "Why did he raise this problem? Why not just come to me individually and quietly point it out....?" He wondered in a passage reflecting the negative emotional dimension of criticism.

To this point in the story, Kim's reluctance, ignorance, and apprehension stood in for the larger social problem faced by the Party as it sought to routinize criticism among the wider population. His affective response - resentment - and his initial resistance to criticism was precisely what these types of stories sought to dissipate. Unsurprisingly for this type of hortatory story, the account shifts tone with Kim's evolving comprehension. Despite his frustrations, Kim recounts how he came to acknowledge the power of the criticism, as it made him begin to focus on reducing the defects in his work. The narrative of a dawning self-awareness is clear. A few months passed. He perfected the cutting technique. Soon afterwards one of the wall newspapers at the factory included an article with the title, "Comrade Kim Ǔngsŏn Received Criticism Properly." It was only then, Kim wrote of this revelatory moment, that he became fully aware of the function of criticism. His initial negative reaction resolved itself in this ideal story as his own thinking evolved.

The point of Kim's story was neither his improved technique nor the resultant better production; instead it lay in the overcoming of his earlier misgivings about criticism. Any note of ill at ease completely disappeared, as he accepted the self-improving power of criticism: "If I hadn't received and accepted the sharp criticism and advice from my comrades, I probably would have made more mistakes and not gotten the results that I did. Criticism is certainly a powerful weapon for correcting shortcomings and advancing our goals (saŏp)." In this most personal of accounts, Kim affirms the point made more theoretically by Ri Hongjong: criticism enabled individuals to change their ways to contribute more fully to collec- 
tive goals, only for Kim it was not a matter of a grand scale like Party politics or material dialectics. In places where no criticism is offered or criticism was not welcomed, he writes, advances are not made - the ultimate goal of criticism, "the most noble morality" to which Kim had awakened. There was - in Ri's combative words and now Kim's more pedestrian example - nothing to fear.

\section{The Practice of Persuasion}

Formal explanations like Ri's and exemplary cases like Kim's certainly offered an ideal vision of how criticism should work. But such efforts to explain the purpose and assuage apprehension raised as many questions as they answered. What constituted proper criticism? When and how should it be made? Kim Ǔngsŏn's case appeared much simpler than many, given it ultimately centered on poor technical practices at work that effected production. How was criticism to extend beyond work practices? Such questions, though never directly raised, were hinted at by the outpouring of articles that exhibited concern about the direction that the energies unleashed by criticism might take. The concern with the proper use of criticism arose precisely because there had been too many reports of its improper use.

This concern powered a second stream of writing that sought to promote what were deemed as the best practices for criticism. Much of this centered on the potential for abuse. Again, first person narratives captured this dilemma of how to go about criticizing without alienating people, often achieved by showing the very real challenges faced by ideology workers. If Kim Ŭngsŏn could admit that criticism had rankled him, how then to ensure that the manner of meting out criticism would not result in similar such unfavorable results? One response came to be directed at those performing the criticism, particularly propaganda workers, who were often at the forefront of introducing criticism to the work place.

One such case involved Chŏn Chonggwan, a propaganda worker at a 
machine factory who noticed a pair of his co-workers who had less than salutary sanitation practices. ${ }^{19}$ Neither of them, Chŏn complained, cared about their personal hygiene: they wore dirty clothes and did not get their haircut. In the type of classic connection between personal hygiene, collective property and production, which underlay much of the biopolitics in the postwar era, the account of these personal shortcomings translated over to their work habits, as the pair of workers allowed dust to accumulate on the machines and a general disorder to prevail - a situation that, Chŏn explains, led to numerous accidents. As he recounts, he could not bear it. After their shift finished one day, he approached them, asking them why they didn't keep their machines and bodies clean? He followed up with a warning: if they continued to behave in this way, then he would post a criticism in the factory wall newspaper "so everyone would know". This was tantamount to a threat: criticism as a form of public embarrassment.

If Chŏn's piece concerned criticism, it was also about his own struggle to figure out the best means to pursue his responsibility. So, too, was the article a type of self-criticism of his own use of criticism. As was typical in this kind of self-enlightening narrative, Chŏn soon recognized his initial mistake. He explained that the two workers he criticized reacted by refusing to engage with him - all without reforming their habits. He had failed - or, more specifically, the form that his criticism took had failed. His point was not to question the act of criticism itself but to explain his failure on how he had voiced his reservations.

In the postwar years, it become common for the KWP to differentiate between persuasive techniques of policy implementation and the errant use of threat by its officials. The former method, of course, became the explicit means of overcoming the type of fears that Chŏn detected in the two workers. At this point, Chŏn realized the point - one regularly made

19 Chŏn Chonggwan, "Wisaeng munhwa saŏp ŭl kanghwahagi wihan sŏndong esŏ ŭi naŭi kaebyŏl tamhwa" (My conversations in the propaganda effort to strengthen hygiene culture), Sŏndongwŏn such'ŏp 14 (July 1958) 27-28. 
in the media and the main point of his account - that using criticism as a form of threat to exhort change was an ineffective technique. ${ }^{20}$ Instead, Chŏn recounts that he learned to take a slower, more patient approach. He soon apologized to the two workers for his coercive behavior and began talking to each of the workers individually about the relationship between personal hygiene and productive work. As expected in such narratives, the shift to a more persuasion-oriented strategy worked: the two workers began taking care of their personal hygiene together with the sanitary conditions of their workplace - and their production reached $130 \%$ of their quota, always an affirmation of any initiative. Instead of being criticized with social embarassment, the experience of one of the two workers was written up in a praise-filled wall newspaper story, entitled story "Comrade Lee - Yesterday and Today." The narrative impetus was clear: an unthreatening criticism induced behavioral change, which in the end turned into public praise. In this account both Chŏn and the two workers are shown are shown as succeeding, the latter in their work and the former in the effective use of criticism.

Chŏn's account about the abusive potential of criticism was a relatively mild one. As frequent as these types of concerns arose in the press and as much as such stories revealed the very real anxieties about criticism, such reports tended toward a lightness of tone. Cartoons might mock low level officials for not taking a persuasive approach with their underlings. ${ }^{21}$ An account of school children establishing a hygiene inspection station at the front gates of their school, meting out criticism and punishments to those they deemed under the bar might chide them for overzealousness. ${ }^{22} \mathrm{Car}-$

20 For one reader's submission on this issue see Pak Chŏnghŭi, "Sŏlbok kwa kyoyang ŭl ap'seuja (Let's Persuasion and Refinement Lead), " Rodongja sinmun (The Newspaper for Workers) July 29, 1959.

21 Officials also received criticism for relying on coercion rather than persuasion in dealing with their underlings. For one cartoon mocking two types of officials, see "Naega pon tu chingmaeng ilggun" (Two Federation workers I have seen) Rodongja sinmun (The Newspaper for Workers) July 8, 1959.

22 Significantly, the children were chided for taking the initiative without the supervi- 
toons could mock the tendency of some to aggressively pursue criticism of others while only gently criticizing themselves. ${ }^{23}$ Similarly, low level officials could be satirized for boldly criticizing the higher officials in their organization but, in turn, preventing their own criticism from below. ${ }^{24}$ The growing currency of the expression "comradely advice" seems to have been directed at ensuring that criticism would remain constructive and not devolve into personal bickering or gossip. ${ }^{25}$ These concerns limited themselves to tactics as to how to go about doing criticism most effectively. The resulting contrast between persuasive and coercive criticism arose to structure these concerns, an either-or proposition that ignored the difficulties in making these distinctions and assumed everyone would be willing to accept properly meted out criticism. What is important in these examples is not so much the idiosyncrasies of the individual cases but the fact that these types of concerns were sufficient that the editors and writers of KWP sanctioned publications devoted considerable attention to their discussion and resolution. The authorities were keen to ensure that the practice of criticism did not lead to alienation but served its ideological and political purposes.

In the comparative study of historical socialism, criticism has always had an intimate relationship with class struggle after revolutions. The relationship was clear in the early years of Stalinist Russia. In the PRC, the use of class at the time of the Great Leap Forward was only overshadowed by its diverse and competing usages during the Cultural Revolution. In the DPRK, however, class discourses did not get embroiled in the type

sion of their teachers For one case where criticism in schools became what today we would call bullying, see "Min'chong mit sonyŏndan yŏlsŏngja tongmu tŭl ege" (To the enthusiastic comrades of the Youth League and Children's Corps) Saesedae (The New Generation) August 1955.

23 This comic was reproduced from a Chinese source. Ch'ŏngnyŏn saenghwal (The Life of Yuth) 69 (June 1955) 59.

24 Ch'ŏngnyŏn saenghwal (The Life of Yuth) September 1954: 53.

25 This phrase occurred frequently in the Nodongja sinmun (The Newspaper for Workers). 
of tumultuous politics as in its two socialist neighbors.

After the war, at least three types of class discourse co-existed. ${ }^{26}$ None of these were exclusive to the others and they often came to be intertwined. The first might be called (in no particular order) the classic Marxist class categories, as most famously captured in some of the show trials of prominent survivors from the colonial period such as Yi T'aejun and in the immediate postwar purging of landlords during the land reforms. So, too, were the merchants who after the war played a key role in reviving economic circulation, deemed by these classic terms - 'petit bourgeois' for their specific case. Here class was structurally defined according to an individual's relationship to the means of production. In the context of the 1950s, this was often highlighted as the struggle against bourgeois and petty bourgeois thought. ${ }^{27}$

A second type, which has captured the imagination of contemporary human rights advocates, consisted of a hierarchical political categorization of the population. Implemented to a certain degree beginning at the end of 1958, this system has come to be known, even in English, as sŏngbun. ${ }^{28}$ While the rigidity of the early history of this system has been

26 My thinking on this co-existence of different notions of class has been shaped by several authors working on Soviet and PRC history, including Richard Kraus, Class conflict in Chinese Socialism. New York: Columbia University Press, 1981; the many works on this subject by Sheila Fitzpatrick, including Educational and Social Mobility in the Soviet Union, 1921-1934. Cambridge: Cambridge University Press, 1979; Stephen Kotkin Magnetic Mountain: Stalinism as Civilization. Berkeley: University of California Press, 1995; and Yiching Wu, The Cultural Revolution at the Margins: Socialism in Crisis. Cambridge, M.A.: Harvard University Press, 2014.

27 For one example, see Kim Tongch'ol, “Kŭlloja tŭl sok esŏ ŭi purŭjyoa chŏk mit so purŭjyoa chŏk chanjae ŭisik ŭi kŭkpok ŭl wihaesŏ" (Towards overcoming the remaining bourgeois and small bourgeois ideological elements from among the workers) Kŭlloja (The Laborer) 1955.7: 75-89.

28 For one ahistorical account see Robert Collins, Marked for Life: Songbun - North Korea's Social Classification System. Washington D.C.: Committee for Human Rights in North Korea, 2012. 
highly exaggerated and any social historian let alone student of comparative socialist history would question the ability of a state to make such categories 'fit' complex social realities on the ground, in its conception at least sŏngbun rested on a conceptual hodge podge of political loyalty, historical experience, and class affiliation, as rather impossibly captured on a familial basis. ${ }^{29}$

Finally, there was what might be called the universal and inclusive socialist subject - what was widely promoted by the KWP as proletarian consciousness. This was the class category to which, in theory, virtually the entire population but those explicitly relegated to the bourgeiois camp should aspire. This mode of speaking about class in the DPRK has largely been derided, recognized only for the way it is honored in the breach. There is little doubt that in the DPRK this ideal subject, much like its ideal liberal counterpart in other settings, was riven by all sorts of cleavages. In the postwar period, the privileging of the masculine and the urban behind this veil of universality is obvious, despite the KWP's revolutionary discourse supposedly relegating these biases to the pre-liberatory past. ${ }^{30}$ Despite these contradictions, the ideal of a socialist subject as extending to most people remained arguably the preeminent way of speaking about class in the DPRK. My point is not to suggest that this ideal was ever achieved. Its claim to inclusivity in particular lay in tension, conceptually as well as in practice, with the less public discourse on sŏngbun. Never-

29 Yi Paksu, "PukHan ŭi kyegŭp kujo e kwanhan yŏn'gu." (The Research on the structure of the class) In PukHan üi hyŏnsil (The real of North Korea). Seoul: Asea Munje Yŏn'guso, 1981; Kim Namsik, PukHan kongsanhwa kwajŏng y'ŏn'gu (Research on the Process of North Korea's Communization). Seoul: Asea Munje Yŏn'guso, 1972. Also, in English see Robert Scalapino and Chong-sik Lee, Communism in Korea, volume 2. Berkeley: University of California Press, 1972: 831844.

30 There has been much research on the topic on gender policies, specifically concerning women, yet few other cleavages have been subject to study. One of the earliest studies on women see Yun Miryang, Pukhan yŏsŏng chŏngch'aek (The Policy on Women in North Korea). Seoul: Hanŭl, 1991. 
theless, anyone wishing to participate in DPRK political discourse necessarily invoked the notion of the socialist subject. It was the language of North Korean socialism.

To take the DPRK discourse on the socialist subject seriously is not to suggest the actual existence of an egalitarian, post-class society. If anything, the combined work of scholars such as Sŏ Tongman, Kim Seungbo, Kim Kwangsik, Yu Inch'ŏl, and Han Sŏnghun have shown quite clearly that the social revolution of the post-1945 period was increasingly leading to the formation of a new governing elite, however much their background was among the workers and peasants. ${ }^{31}$ This North Korean experience parallels the rise of new post-revolutionary class relations in the Soviet Union with the rise of a technocratic under Stalin and, in China, the formation of a bureaucratic elite despite Mao's efforts. There is still little understanding of how this growing North Korean elite functioned as a class in specific moments of time and space. Nevertheless, it was in the very same era when this new governing class was in the process of formation that the discourse of the universal socialist subject became so powerfully disseminated.

In this context, the relationship between ideology and class took on a highly politicized form - and criticism became a charged realm for its articulation. Yet judging from workers' criticisms that are available to us, criticism in the workplace took some very specific forms belying their

31 Sŏ Tongman, PukChosŏn sahoejuŭi ch'eje sŏngnipsa (The History on the Establishment of Socialism System in North Korea), 1945-1961. Seoul: Sŏnin, 2005; Kim Seungbo, NambukHan kyŏngje kujo ŭi kiwŏn kwa chŏngae (The Origin and Development of Economic System in South and North Korea). Seoul: Yŏksa Pip'yŏngsa, 2000; Yi Chuch'ŏl, Chosŏn Nodongdang dangwŏn chojik yŏn'gu, 1945 1960 (Research on the Membership and Organization of the Korean Workers' Party). Seoul: Sŏnin, 2008; Kim Kwangun, Pukhan chŏnch 'isa yŏn'gu I (The Study on the Political History of North Korea). Seoul: Sŏnin, 2003; and Han Sŏnghun, Chŏnjaeng kwa inmin: Pukhan sahoejuŭi ch'eje ŭi sŏngnip kwa inmin ŭi tansaeng (War and People: The Establishment of Socialism System and the Birth of People in North Korea). Seoul: Tolbegae, 2012. 
grand revolutionary purpose. Indeed, although criticism received much attention as a form of ideological preparation, the actual tone of the criticism was often muted and rendered highly personal. In the way Ri's robust language of class warfare found little place among the ideological workers carrying out criticism in the local social worlds of the factory, invocations of class struggle remained rare, as workers turned the high politics of revolution into the more mundane problems confronted in the workplace.

\section{'My Turn to Speak'}

In the late 1950s the newspaper of the General Federation of Trade Unions, the Rodongja sinmun, featured a regular forum for workers to offer brief criticisms of a startingly wide range of practices and behaviors. Entitled "My Turn to Speak" (Nado han madi), these one-off criticisms consisted of short outbursts of barely contained frustration and, in cases, outrage. Selected and edited by the newspaper's staff, these criticisms assumed a more colloquial air than was the norm for this newspaper, which in tone was already quite 'lowbrow' in comparison to the 'highbrow' central newspapers like Rodong sinmun or Minju Chosŏn. These public criticisms were certainly not unmediated popular voices. They were still selected and published in a paper run by one of the key mass organizations of the Party. Yet these minimal texts - sometimes as short as five lines, sometimes as long as two paragraphs - also offer a type of fragmented insight into the general unruliness of postwar urban life, one of the very motivations for the Party to push for the dissemination of criticism in the first place. That they were published gives some sense of the approved realms for public criticism as well as their mundane manner of articulation - a forum for criticism vastly different from the postwar show trials.

Strikingly, these short pieces always emphasized the individual. Virtually every piece named the critic and the recipient of the critiquing, listing their workplace and often naming other co-workers. There was no hiding. 
This emphasis on the individual reflected the ways the KWP assessed the lagging levels of ideological rectitude among the population. Given the official achievement of socialism in 1958, one's ideological level now reflected not so much the material conditions of society or one's relationship to the means of production - the old Marxist category of class - but how an individual had internalized or struggled to achieve the norms expected of proletarian consciousness. The criticisms in "My Turn to Speak" reflected the widespread framing of proletarian consciousness in a form of socialist culturalism. In place of structural understanding of class and ideology, these criticisms are rich in a range of nebulous but powerful terms such as "outmoded thought" (nalgŭn sasang) and the more storied concept of munhwa saenghwal (cultural life), with its genealogy linking it to Soviet concepts of kulturnost as well as synonymous terms from the colonial era. ${ }^{32}$ Such terms, with their assumptions of the existence of a reformable individual, framed criticisms not as a task of coming to terms with one's material position in society but of struggling within one's self to eliminate bad habits and ascend to the thoughts and behavior deemed appropriate for socialism. The onus was on the self. The criticisms in "My Turn to Speak" give us a sense of the range of idiomatic engagements of workers in their local social worlds with criticism culture.

Hygiene appeared as a regular topic of concern for workers. Hŏ Sŏngmun was charged by one of his dormitory mates, Sŏ Yŏngbŏom, as having the messiest of rooms, with clothes strewn around and the stench of sweat piercing the air. "Every month when he gets his salary, he wastes it in on gambling. He is uninterested in pursuing a cultural life. How is this OK?" ${ }^{33}$ Hygiene - one of the most written about topics in the DPRK me-

32 On the Soviet concept, see Vadim Volkov, "The Concept of Kul'turnost': Notes on the Stalinist Civilizing Process," In Sheila Fitzpatrick, ed., Stalinism: New Directions. London: Routledge, 2000; in Japan, see Harry Harootunian, Overcome By Modernity: History, Culture, and Community in Interwar Japan. Princeton: Princeton University Press, 2000.

33 "Nado han madi," (My Turn to Speak), Rodongja sinmun (The Newspaper for Workers), June 71959. 
dia in the decade after the war - also offered a realm safe for the critique of low level officals, especially factory leaders. A worker in the $8^{\text {th }}$ construction unit of the electricity bureau, Ri Sŏk reported that workers had been complaining since the previous year about their broken bathing facilities, which were still not working. The situation reflected the fact that the leaders of the third unit "were not sufficiently concerned about the livelihood of workers." 34 A similar situation existed at the Pyongyang Textile Machine Factory, where the arguments between the leadership of the factory had caused delays in the construction of bathing facilities. Noting that worker morale was sagging, Ch'oe Tŏkkil recalled, "Last time when the daycare facilities were being built, there were the same problems. Has that lesson been forgotten?!" 35

Complaints about colleagues' work discipline was often couched in the language of cherishing the value and pleasures of labor. This is what disgruntled Ko Myŏngjin about his construction co-worker, Yi Tongsŏp, a skilled musicisan, who according to Ko claimed he had nothing to learn at the work place, hated working, and often skipped off. Yi "is good at music," explained Ko, and keeps asking to be sent to music school rather than work, " How can a person who doesn't like to work play genuine music?"36 Some criticisms engendered responses from other readers. Hong Ǔngun became so infuriated by one six line entry about a doctor, Kim Sunhŭi, who left work at the end of the day rather than stay late to treat a patient who was running a temperature above 40 degrees that he sent in a response from his work place in Khaborovsk, "Comrade Kim Sunhŭi must quickly cast aside this kind of outmoded thinking," he wrote, before asking the editors to report back in the pages of the newspaper

34 "Nado han madi," (My Turn to Speak), Rodongja sinmun (The Newspaper for Workers), April 171959.

35 "Nado han madi," (My Turn to Speak), Rodongja sinmun (The Newspaper for Workers), May 131959.

36 "Nado han madi," (My Turn to Speak), Rodongja sinmun (The Newspaper for Workers), June 7, 1959. 
whether she had 'corrected her ideological shortcomings' and was working sincerely. ${ }^{37}$ Comrade Pak Manbong compounded his lackadaisical work with a fierce reluctance to receive criticism. "A few days ago, " began the notice of Ri Hwanju, "Comrade Pak Manbong was processing an important component, but he failed to observe the proper standards. When the factory inspector pointed this out to him, instead of thanking him he got into a fistfight with the inspector. Comrade Pak Mongbong! Does this mean that even when you see something wrong, you think nothing should be said?"38

Comrade Pak's pugnaciousness may not have been explicitly linked to alcohol, but many other writers made the connection. One writer, a rare case of someone retreating to anonymity, wrote about two named senior members of the Chongjin Rubber Factory, who regularly showed up to work reeking of alcohol and causing problems. When another worker, Comrade Pae Yusaeng told them to stop, rather than realize what they were doing, one of them, Comrade Chu Hwanju, a foreman, struck Pae with his fist. "How can you stay quiet about this behavior?" the writer complained. ${ }^{39}$

Umbrage at the absenteeism of co-workers had a special place in $M y$ Turn to Speak. Comrade Kil Iru of a Pyongyang machine manufacturing factory may have been skilled at cut work, but as his colleague Kang Ch'ŏlju fumed, "Pretty much every day he just hangs around on street corners." 40 In another complaint written up by Kim Yusŏng, his coworker Paek Sunhŭi showed up to work, only to complain of pains. She

37 "Nado han madi," (My Turn to Speak), Rodongja sinmun (The Newspaper for Workers), April 19, 1959. The original story had been published on March 18, 1959.

38 "Nado han madi," (My Turn to Speak), Rodongja sinmun (The Newspaper for Workers), May 6, 1959.

39 "Nado han madi," (My Turn to Speak), Rodongja sinmun (The Newspaper for Workers), May 10, 1959.

40 "Nado han madi," (My Turn to Speak), Rodongja sinmun (The Newspaper for Workers), April 171959. 
said she was going to the hospital when in fact she headed out shopping, he charged. ${ }^{41}$ On a more bizarre level, the column reported that a group of workers had left the Kim Ch'aek Ironworks for a holiday in Chongjin; more than two months later they had not returned to work - nor was there any news. ${ }^{42}$

Many of the criticisms defy easy categorization, even though they spoke to the types of concerns in advice literature. Pak Pyŏngsŏ wrote in to complain about a co-worker who did not treat the factory cadres with respect, swearing at them and not greeting them "What kind of thought is that?!" he asked, before concluding that he hoped he would learn to treat people with respect. ${ }^{43}$ Another simply complained that the showing of the drama, "Dark Shadow, "started so much later than announced that workers weren't able to get home until well after midnight, making it difficult to leave home and get in to work the next day on time. Given this, Comrade Rim asked, how are workers supposed to maintain 'order'? ${ }^{44}$

If these outbursts in My Turn to Speak were as short as they were moralizing, letters to the editor in the same newspaper offered more lengthy examples of the growing criticism culture. Like their shorter counterparts, these letters were also filtered by the editing process, yet they, too, had a colloquial ring to them. Nevertheless, the letter writers deployed the language of advice and cultural living to frame and legitimate their criticism - or what was often little more than curmudgeonly complaining. Such was the case of an anonymous writer from the Anju coalmine, who late one night was disturbed by "singing and laughter shaking the night sky." 45

41 "Nado han madi," (My Turn to Speak), Rodongja sinmun (The Newspaper for Workers), July 8, 1959.

42 "Nado han madi," (My Turn to Speak), Rodongja sinmun (The Newspaper for Workers), June 7, 1959.

43 "Nado han madi," (My Turn to Speak), Rodongja sinmun (The Newspaper for Workers), May 31, 1959.

44 "Nado han madi," (My Turn to Speak), Rodongja sinmun (The Newspaper for Workers), 31 July 1959.

45 "Kunjung todŏk ŭl wibanhanŭn sillyŏk ilgun tŭl”" (Workers who Violate the Moral- 
Workers from the nearby railway administration offices, including the office head, had taken over a workers cafeteria for a drinking Party and were "way too drunk." They were making a racket, singing with disorder both popular songs and revolutionary tunes. When a young co-worker saw this scene and advised them to respect the order of the cafeteria, they responded "We're drinking. What does it have to do with you?" The letter writer went on to ask, "Can we say that these are people who have received a communist education? These types of violations of public order are living signs of outmoded thought. Moreover, should railway workers, who serve the people, not know better than anyone else that the morality and order of the masses must be well observed together?!" He closed his letter with a hope: that these workers develop what by the end of the 1950s had become a common phrase - a communist moral character. ${ }^{46}$

Both this letter writer and the many worker critics assumed a moral high ground, writing with a sense that the offender, living in a socialist society, should be doing better and could be doing better. The material conditions existed, so it was up to the individual. The flexible, individuated nature of postwar ideology emerges in these letters strongly. Criticisms of co-workers, of workplace habits, of public behavior, of self-propriety all of these share the individuating impulse that we find in other writings of the era. The explanation for the actions of the named violator rested on his or her shoulders. It was up to the self-aware individual to get their act together, so to speak, and criticism was a means to make them realize this end.

"My Turn to Speak" also offers a peek into the social life of North Korea, about which we know so very little for these years. The logic of criticism required that there be negative behavior and thought against which

ity of the Masses) Rodongja sinmun (The Newpaper for Workers), May 29, 1959.

46 Kim Ilsung takes up this circulating concept in a famous 1958 speech, which affirmed its centrality in North Korean political discourse. The original speech was published in the Rodong sinmun (The Newspaper for Workers) as "Kongsanchuŭi kyoyang e taehayŏ" (On the Cultivation of Communism) on December 9, 1958. 
the appropriate norms could be highlighted and explained. After all, something needed to be done. While the column reveals the existence of these activities or behaviors, they are not surprisingly presented in a negative light. It is not possible to escape the official categories and language by which these behaviors are described - what were those street revelers actually singing? Nevertheless, these criticisms give a sense of the very unruliness on the streets and in the factories that spurred the Party's desire for more ideological work. Good socialists, after all, were not supposed to act this way.

Just as importantly in these criticisms was what was not said. Much of the more theoretical language for criticism used by higher level authorities to mobilize popular criticisms had no place in "My turn to Speak." Newspapers and magazine editorials, following the guidance of the KWP, frequently wrote of the need to criticize such phenomenon as passivity (sogŭksŏng), formalism (hyŏngsikchuŭi) or conservatism (posujuŭi), all of which emerged as standard categories for explaining problems in socialist construction, employed at higher political levels and promoted for use throughout the country, often in campaign-style movements. ${ }^{47}$ The Party's top level theoretical journal continued to speak about class struggle, specifically arguing for the need to eliminate bourgeois and petty bourgeois thought well into the 1960 s. $^{48}$ Yet remarkably in these more mundane cases of criticism, workers simply did not deploy such categories and the newspaper editors clearly did not expect them to do so.

Similarly, none of these criticisms invoked the conventional language of class struggle. None of the selections in 'My Turn to Speak', despite targeting a wide array of (mis)behavior and thought, ever use the label

47 Two examples from this period "Sogŭksŏng kwa posujuŭi rŭl kŭkpokhago tŏ ppalli naagagi wihayŏ" (In order to get out more quickly and overcome passivity and conservatism) Rodong sinmun Oct. 12, 1958; Ri Yangsŏp, "Wisaeng saŏp e taehan hyŏngsikchŏgin chido rŭl sijŏnghaja” (Let's straighten out formalist leadership in hygiene affairs) Rodong sinmun january 24, 1959.

48 "Purŭjyoa sasang kwa ŭi t'ujaeng ŭl tŏuk kanghwa haja" (Let's Strengthen the struggle with bourgeois thought). Kŭlloja (The Workers)1962.9: 21-28 
'bourgeois.' The offending behavior was never labeled bourgeois or feudal. Explanations did not turn to a person's prior class background, whether pre-1945 or before complete socialization in 1958. An individual's background, however defined, did not get cited as the reason to expect that a person might fail to self-reform. Neither classic Marxist categories nor the language of songbun emerged as the open language of criticism. On the contrary, the inclusive logic of the universal ability of good socialist subjects to improve themselves through ideological selfrefinement structured all these criticisms.

As intensely personal as these criticisms were - no doubt it was no fun to be named in a column of "My Turn to Talk" - this personal framing of critique tempered the political charges that could be leveled at co-workers. In the 1950s, to suggest some one was bourgeois or petty bourgeois was a truly serious charge. What does it mean that these criticisms shied away from the revolutionary class conceptions that underlay the KWP's claim to rule as well as the political charges levied at opponents that emerged out of Party congresses? Such serious political labels seem to have been left for high crimes and only the most serious lapses. In the local social worlds of workers - and perhaps more broadly in the political culture of everyday life in the DPRK - criticism became a politically tame yet highly personalized practice. Criticism delved into a wide realm of personal behavior while steering clear of politically labeling individuals. In "My Turn to Talk" perhaps the most charged terminology invoked social order, its violation and disruption. This absence was in stark contrast with contemporary China, where class terminology was everywhere in the daily lives of the population, used to explain much about an individual's behavior, whether in formal settings or in gossip on the streets. ${ }^{49}$ No such situation seems to have existed in the DPRK. There are various possible explanations for this difference, yet this telling contrast between the two neighbors carried with it, arguably, immense political repercussions.

49 For its everyday use among families, see Jie Li, Shanghai Homes: Palimpsests of Private Life. NY: Columbia University Press, 2014. 


\section{Conclusion}

Ultimately, this mundane mode of criticism vacated conventional Marxist understanding of class. What had been an essential tool in the Party's historical use of socio-economic analysis, which had underpinned reforms since 1945, had virtually no role to play in this definition of ideology and individual behavior. Instead of foregrounding one's relationship to the mode of production or highlighting a familial class background, this widespread understanding of ideology placed the contemporary historical struggle inside the individual self. What had once been defined by exterior socio-economic relations now came to rest on an individuals' interior struggle over 'outmoded' aspects of one's thought.

The effect of this mode of writing and speaking about class, ironically, was to de-politicize the very socialist subjects that were its product. This type of inclusive and universalizing definition of the socialist subject was being articulated in the very years that the postwar state and new social relations were in the process of forming anew and consolidating. New hierarchies of power and institutions, focusing largely but not exclusively on the Korean Worker's Party, were developing. Yet this new inward looking gaze that shaped mundane understandings of class and ideology had little potential for offering a critical analysis of the postwar directions of social formations. Their very formation rested on a vision that shifted politics inward and toward the individual at the expense of an outward looking criticism of contemporary class relations. The possibilities of using of class analysis for all historical periods, not just the past but also the contemporary, was rendered less tenable in the local social worlds of workers.

\section{References}

1. Ch'ŏngnyŏn saenghwal (The Life of Youth).

2. Kim Il Sŏng Chŏjakjip (The Works of Kim Ilsung). Pyongyang: No- 
dongdang ch'ulp'ansa (The Labor Party Press), 1979.

3. Kŭlloja (The Workers).

4. Rodong sinmun (The Newspaper for the Labor)

5. Rodongja (The Workers)

6. Rodongja sinmun (The Newspaper for the Workers)

7. Saesedae (The New Generation)

8. Sŏngdongwŏn such'ŏp. (The Memo of Sŏngdongwŏn)

9. Tangganbudŭl ege chunŭn ch'amgo charyo. (The Historical Materials for giving to the Leaders of the Party)

10. Anon. Miguksik saenghwal yangsik kwa namChosŏn e mich'in kŭ hugwa (American Life Style and Its Consequences for south Korea). Pyongyang: Chosŏn Rodongdang Ch'ulp'ansa, 1965.

11. Charles Armstrong. The North Korean Revolution, 1945-50. Cornell University Press, 2003.

12. Collins, Robert. Marked for Life: Songbun - North Korea's Social Classification System. Washington D.C.: Committee for Human Rights in North Korea, 2012.

13. Fitzpatrick, Sheila. Educational and Social Mobility in the Soviet Union, 1921-1934. Cambridge: Cambridge University Press, 1979.

14. Sheila Fitzpatrick and Robert Gellately, eds. AccusatoryPractices: Denunciation in Modern Europe, 1789-1989. Chicago: Chicago University Press, 1997.

15. Han Sŏnghun. Chŏnjaeng kwa inmin: Pukhan sahoejuŭi ch'eje ŭi sŏngnip kwa inmin ŭi tansaeng (War and People: The Establishment of Socialism System and the Birth of People in North Korea). Seoul: Tolbegae, 2012.

16. Harootunian, Harry. Overcome By Modernity: History, Culture, and Community in Interwar Japan. Princeton: Princeton University Press, 2000.

17. Hwang Yŏngsik, Saenghwal ŭi kŏul (A View on Life). Pyongyang: Chosŏn Sahoejuŭi Rodong Ch'ŏngnyŏn Tongmaeng Ch'ulp'ansa (The Press of Chosŏn Socialism Labor Alliance), 1965.

18. Kim Chaeung. "PukHan ŭi inmin kukka kŏnsŏl kwa kyekŭp kujo 
chaep'yŏn, 1945-1950" (The Construction of the People's State and Re-organization of Class Structure in North Korea, 1945-1950). Seoul: Koryo University dissertation, 2014.

19. Kim Kwangun, Pukhan chŏngch'isa yŏn'gu I (North Korean Political History Studies I). Seoul: Sŏnin, 2003.

20. Kim Namsik. PukHan kongsanhwa kwajŏng y'ŏn'gu (Research on the Process of North Korea's Communization). Seoul: Asea Munje Yŏn'guso, 1972.

21. Kim Seungbo. NambukHan kyŏngje kujo ŭi kiwŏn kwa chŏn'gae (The Origins and Development of North and South Korean Economic Structures). Seoul: Yŏksa Pip'yŏngsa, 2000.

22. Kim, Suzy. Everyday Life in the North Korean Revolution, 19451950. Ithaca: Cornell University Press, 2013.

23. Kotkin, Stephen. Magnetic Mountain: Stalinism as Civilization. Berkeley: University of California Press, 1995.

24. Kraus, Richard. Class conflict in Chinese Socialism. New York: Columbia University Press, 1981.

25. Li, Jie. Shanghai Homes: Palimpsests of Private Life. NY: Columbia University Press, 2014.

26. Pak Kumch'ŏl. Tang ŭi t'ongil kwa tangyŏrrŭl tŏuk kanghwahald e taehayŏ (For the Further Strengthening of Party Unity and Solidarity). Pyongyang: Chosŏn nodongdang ch'ulp'ansa (The Labor Party Press), 1958.

27. Scalapino, Robert and Chong-sik Lee, Communism in Korea, volume 2. Berkeley: University of California Press, 1972.

28. Sŏ Tongman. PukChosŏn sahoejuŭi ch'eje sŏngnipsa, 1945-1961 (The Establishment of the North Korean Socialist System, 19451961). Seoul: Sŏnin, 2005.

29. Volkov, Vadim. 'The Concept of Kul'turnost': Notes on the Stalinist Civilizing Process," In Sheila Fitzpatrick, ed., Stalinism: New Directions. London: Routledge, 2000.

30. Whyte, Martin King. Small Groups and Political Ritual in China. Berkeley: University of California Press, 1974. 
31. Wu, Yiching. The Cultural Revolution at the Margins: Socialism in Crisis. Cambridge, M.A.: Harvard University Press, 2014.

32. Yi Chuch'ŏl. Chosŏn Nodongdang dangwŏn chojik yŏn'gu, 19451960 (Research on the Membership and Organization of the Korean Workers' Party). Seoul: Sŏnin, 2008.

33. Yi Paksu. "PukHan ŭi kyegŭp kujo e kwanhan yŏn'gu." (The Research on the structure of the class) In PukHan üi hyŏnsil (The real of North Korea). Seoul: Asea Munje Yŏn'guso, 1981.

34. Yun Miryang. Pukhan yǒsŏng chŏngch'aek (The Policy for Women in North Korea). Seoul: Hanŭl, 1991. 
$<$ Abstract $>$

\section{"My Turn to Speak": Criticism Culture and the Multiple Uses of Class in Postwar North Korea}

Andre Schmid

This paper examines the vexed and complex relationship between class, ideology and criticism in 1950s North Korea after the end of the Korean War. Although the KWP presented class as an unitary category, there were in fact many ways of writing about class in these years. Rather than use high-level KWP sources for a single 'authoritative' definition of class, this paper examines sources read in the local social worlds of workers. The paper first examines the anxieties created by the implementation of self and group criticism and the measures taken to mollify these worries. It next considers workers' criticisms of their colleagues published in the Nodongja sinmun. These writings show how class discourse among workers vacated traditional Marxist discourses on class to become more of a cultural category designed to promote self-evaluation and self-reform.

Keywords: North Korea, class, criticism, ideology, criticism culture, Nodongja sinmun 
<국문초록>

\section{"나도 한마디": 전후 북한에서의 비판 문화와 계급의 다목적 사용}

안드레 슈미드 (토론토대학교 동아시아학과 부교수)

이 글에서는 한국 전쟁이 끝난 이후 1950년대 북한에서 존재했던 계급, 이데 올로기 그리고 비판 사이의 복잡하고 곤란한 관계들에 대해서 분석하였다. 비록 조선노동당이 단일한 범주로서 계급을 대표하긴 했지만, 실제로 북한에서는 그 기간 동안 계급에 대한 다양한 글쓰기 방식들이 존재했다. 이 글은 단일하고 '권 위적인' 계급의 정의를 위한 조선노동장의 높은 차원의 자료보다 노동자들의 지 역적이고 사회적인 세계에서 다루어졌던 이야기들을 분석하였다. 이 글은 먼저 자기/집단 비판의 시행에 의해서 만들어진 불안과 이러한 불안과 걱정을 달래기 위해 사용되었던 수단들에 대해 분석하고 있다. 그리고 '노동자신문'에서 출간된 노동자들의 그들 동료들에 대한 비판을 분석하였다. 이러한 글들은 노동자들 사 이의 계급 담론이 자기 평가와 자기 혁신을 촉진시키기 위해 계급에 대한 전통 적인 맑시즘 담론에서 좀 더 문화적인 범주로 변화해나가는 모습을 보여주고 있 다.

주제어: 북한, 계급, 비판, 이념, 비판문화, 노동자신문 
